\title{
Behaviour of Disconnected and Connected Piled Raft Foundations Subjected to Compressive Load
}

\author{
Kajal Tarenia ${ }^{1}$, Nihar Ranjan Patra ${ }^{1}$ \\ ${ }^{1}$ Indian Institute of Technology, Kanpur, Department of Civil Engineering \\ Uttar Pradesh, India \\ kajal@iitk.ac.in; nrpatra@iitk.ac.in
}

\begin{abstract}
In this paper, both connected and disconnected piled raft foundations subjected to compressive load have been analyzed using PLAXIS 3D considering time effects. Pile rafts of size single pile, $3 \times 1,3 \times 3$ and $5 \times 5$ have been considered in the analysis. The field study reported by Mattsson et al. (2013) has been considered for the analysis and validation. In PLAXIS 3D, the soil model consists of 10-noded tetrahedral soil elements. The piles are modelled with the use of embedded pile option. The calibrated parameters from the analysis have been taken for the prediction of settlement of raft and pile heads with respect to time for both connected and disconnected pile rafts. The settlement of concrete slab of $3 \times 3$ disconnected piled raft foundation obtained by PLAXIS 3D is 22\% less as compared to the measured field test values for a period of six months. The settlements of slab of connected piled raft foundations are about $13 \%$ to $68 \%$ lower as compared to disconnected piled raft foundations irrespective of pile group configurations for a period of one year. The settlements of pile heads of connected piled raft foundations are about $20 \%$ to $65 \%$ lower as compared to disconnected piled raft foundations irrespective of pile group configurations for a span of one year. The settlement of slab and pile heads of $5 \times 5$ connected piled raft foundation has least settlement than other piled raft foundations for a period of one year.
\end{abstract}

Keywords: Numerical Analysis, Pile Raft, PLAXIS 3D, settlement, time effect.

\section{Introduction}

Piles act as settlement reducers in case of piled- raft foundations and hence reducing the settlements of raft. The piles are structurally connected to the raft in a piled-raft foundation (PRF) whereas piles are disconnected to the raft in a disconnected piled- raft foundation (DPRF). In a piled- raft foundation, if there is a larger spacing between the piles, then the axial load per pile will increase, and the structural capacity of the pile can become critical. Alternative way is therefore to disconnect the piles from the raft by introducing an interposed granular layer. In this case, piles act as a means of soil reinforcement and the factor of safety against structural failure can be significantly reduced. Poulos (2001) performed 2D numerical modelling. He used the theory of plate-on-spring and tested the effect of various parameters like thickness of raft, number of piles and pile length in a group of piled- raft on the load shared by piles and the raft and bending moment in raft. Small and Zhang (2002) analysed the behaviour of piled- raft foundations (PRFs) under vertical and lateral loads respectively through the program APRAF (Analysis of Piled Raft Foundations). Horikoshi et al. (2003a) analysed the effect of static horizontal and vertical load on the behaviour of CPRF (combined piled- raft foundations), pile groups, and rafts. Horikoshi et al. (2003b) did centrifuge shake table tests and observed the behaviour of CPRFs and pile groups. Matsumoto et al. (2010) studied the outcome of lateral load on pile groups, raft foundations and CPRFs by carrying out 1-g tests. Sinha et al. (2016) did 3D finite element analysis by using ABAQUS to study the behaviour of piled-raft foundation. Kumar et al. (2016) modelled a CPRF system using PLAXIS 3D from the experimental work obtained by Horikoshi et al. (2003a,b) and numerical work obtained by Eslami et al. (2011). They analyzed the model subjected to static, dynamic and pseudo-static loading conditions. Time dependent behaviour of piles and PRFs in soil are limited (Abbas et al. 2010; Fattah et al. 2013; Mattsson et al. 2013; Mishra and Patra 2018; Poulos 1994; Small and Liu 2008). Mattsson et al. (2013) did a full-scale in situ test for a period of six months. They stated difficulty in choosing the soil parameters which the full-scale test had for the design of ICEDA. Mishra and Patra (2018) predicted the long-term settlement behaviour of pile groups using two different viscoelastic soil models, a nonlinear five-parameter model (a Hookean spring element and two Maxwell elements all connected in parallel) and a linear five-parameter model.

From the literature studies, it is concluded that studies on the behaviour of both connected and disconnected piled- raft foundations considering time effect are limited. In this study, finite element analysis have been carried on both 
disconnected and connected pile raft foundations of size single pile, $3 \times 1,3 \times 3$ and $5 \times 5$ pile groups subjected to compressive loads considering time effect. The field study reported (Mattsson et al. 2013) on disconnected piled raft with embankment loading has been considered for validation and analysis. A comparative study in terms of settlement of slab and deformation of pile heads for both disconnected pile rafts as well as connected piled rafts have been made.

\section{Numerical model and validation}

In this paper, both disconnected and connected pile raft foundations of size single pile, $3 \times 1,3 \times 3$ and $5 \times 5$ pile groups are numerically modeled using the finite-element software PLAXIS 3D. The calibrated parameters that are reported in Mattsson et al. (2013) have been used. The field instrumentation is shown in Fig. 1. Four layers of clay have been taken for the analysis of the numerical model. The three dimensional mesh for $3 \times 3$ disconnected and connected piled- rafts are shown in Fig. 2 and Fig. 3. For disconnected piled-raft, the mesh consists of 13201 elements representing the soil and the concrete piles, and 1798 elements representing the concrete slab. Due to the symmetrical layout, one-fourth of the full model is reproduced in the numerical model. A linear elastic model is considered for the concrete elements in the model. The soil is constituted by elasto-plastic constitutive models such as modified Cam Clay for the clay and Mohr-Coulomb for the embankment fill, upper granular layer and molasse. The calculations are carried out taking into account the coupled behavior of deformation and flow as well as the time-dependent effect of consolidation linked to the permeability of the soil. The length of piles for disconnected and connected pile raft foundations are $36.5 \mathrm{~m}$ and $39 \mathrm{~m}$ respectively. The pile diameter remains the same for all cases i.e. $1 \mathrm{~m}$. The spacing of piles remains same i.e. $5 \mathrm{~d}$ where $\mathrm{d}$ is the diameter of pile. The raft dimensions changes according to the number of piles. For the group of 9 piles, $11 \mathrm{~m} \times 11 \mathrm{~m}$ raft size is provided as mentioned by Mattsson et al. (2013). For the group of 25 piles, $21 \mathrm{~m} \times 21 \mathrm{~m}$ raft size is provided. For $3 \times 1$ line pile group, $11 \mathrm{~m} \times 1 \mathrm{~m}$ raft size is provided. For the single pile, $1 \mathrm{~m} \times 1 \mathrm{~m}$ raft size is provided. The raft thickness remains the same i.e. $1.2 \mathrm{~m}$ for all cases.



Fig. 1: Layout of full-scale test: Field instrumentation (Adopted from Mattsson et al. 2013).

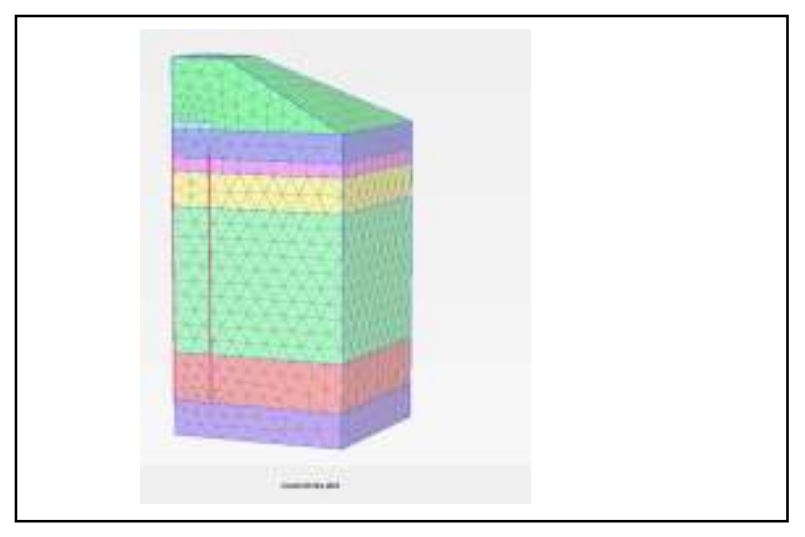

Fig. 2: Numerical model (Disconnected piled raft).

The numerical results of disconnected piled raft of $3 \times 3$ pile group have been compared with the reported results of Mattsson et al. (2013) (Fig. 4). It is observed that the settlement of the concrete slab of disconnected piled raft from the present analysis is consistent with the reported results by Mattsson et al. (2013) and is within an error of 20\%. Also, convergence analysis has been carried out considering coarse, medium and fine meshing. It has been observed that fine mesh of size 14999 elements (including soil and slab) gives better results (about 20\% error). The numerical results by Z_soil software (Mattsson et al. 2013) predicts 40 to $50 \%$ higher settlement on concrete slab of $3 \times 3$ disconnected piled raft as compared to measured value. The accuracy from the present analysis gives results within $20 \%$ error. 


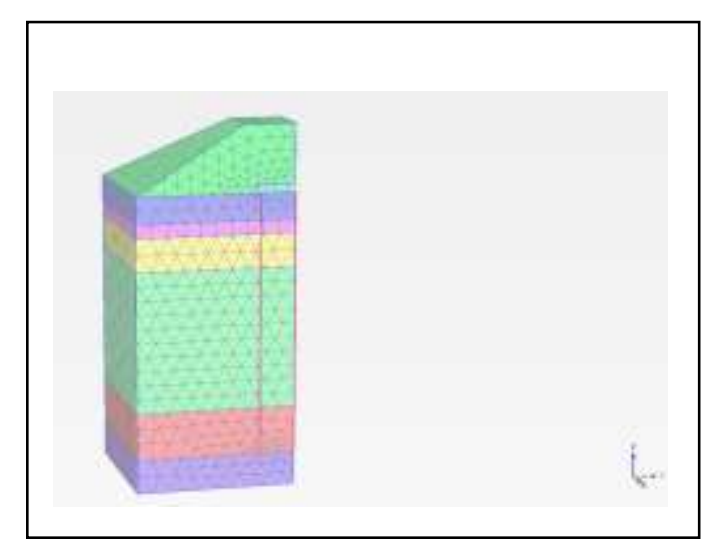

Fig. 3: Numerical model (Connected piled raft).

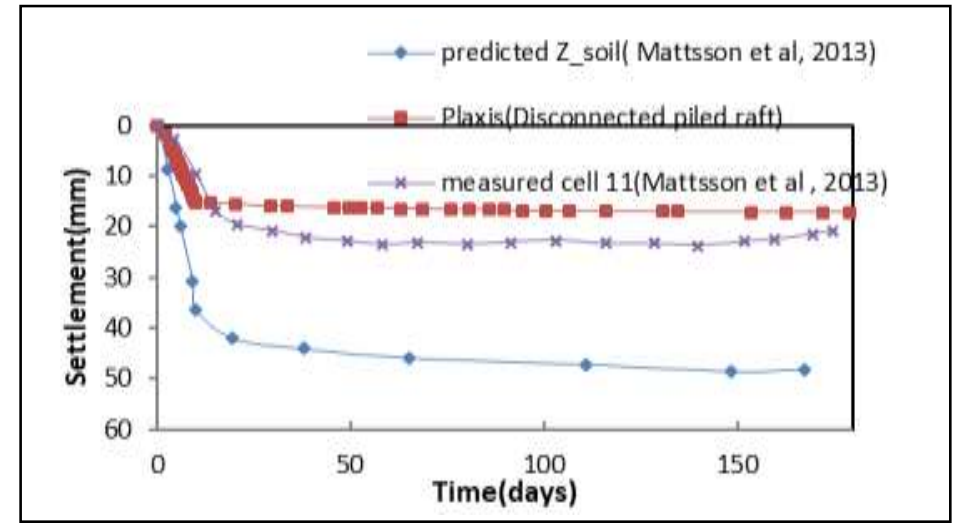

Fig. 4: Measurement and calibrated prediction of settlement on concrete slab for six months.

\section{Numerical results and discussion}

\subsection{Settlement of slab}

Fig. 5 shows the deformation of concrete slab at settlement cell 11 (S11) for a time period of 1 year. The settlement of concrete slab of single connected piled raft is about $41 \%$ less than the settlement of disconnected single piled raft. The settlements of concrete slab of $3 \times 1,3 \times 3$ and $5 \times 5$ connected piled rafts are about $18.83 \%$ to $96.53 \%$ less than the settlement of single connected piled raft for about 1 month to 1 year. The settlements of concrete slab of $3 \times 1,3 \times 3$ and $5 \times 5$ disconnected piled rafts are about $46.02 \%$ to $94.51 \%$ less than the settlement of single disconnected piled raft for about 1 month to 1 year.

\subsection{Settlement of pile heads}

Fig.6 shows the deformation of pile heads at cell 4 (S4) for a time period of 1 year. The settlement of pile heads of single connected piled raft is about $20 \%$ less than single disconnected piled raft. The settlements of pile heads of $3 \times 1,3 \times 3$ and $5 \times 5$ connected piled rafts are about $7.17 \%$ to $87.77 \%$ less than the settlement of single connected piled raft for about 1 month to 1 year. Similarly, the settlements of pile heads of $3 \times 1,3 \times 3$ and $5 \times 5$ disconnected piled raft are about $12.45 \%$ to $65.77 \%$ less than the settlement of single disconnected piled raft for about 1 month to 1 year. It is observed from the results that as the number of piles increase, there is a decrease in the settlement of pile heads. The settlement of the pile heads of $5 \times 5$ connected piled raft is the least among all. 


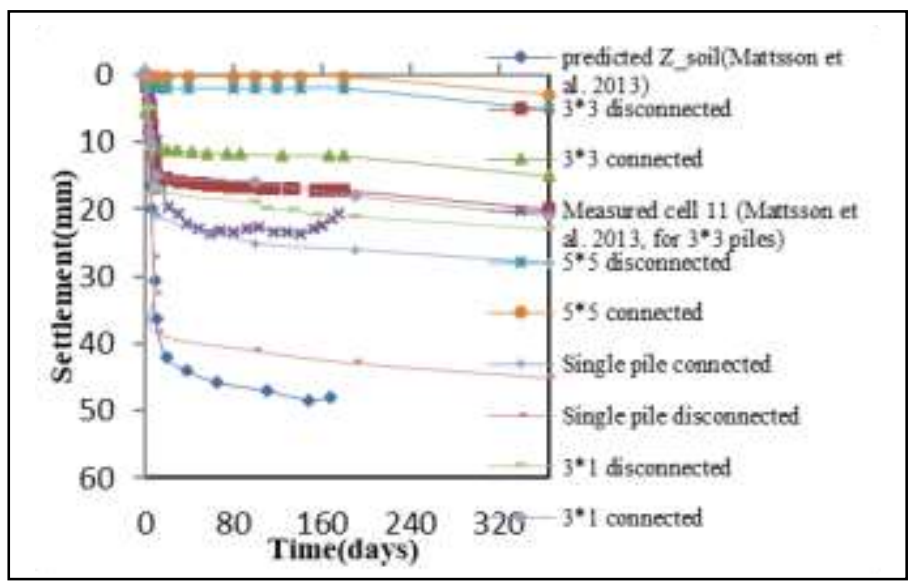

Fig. 5: Settlement of concrete slab for both disconnected and connected piled raft foundation for a period of 365 days.

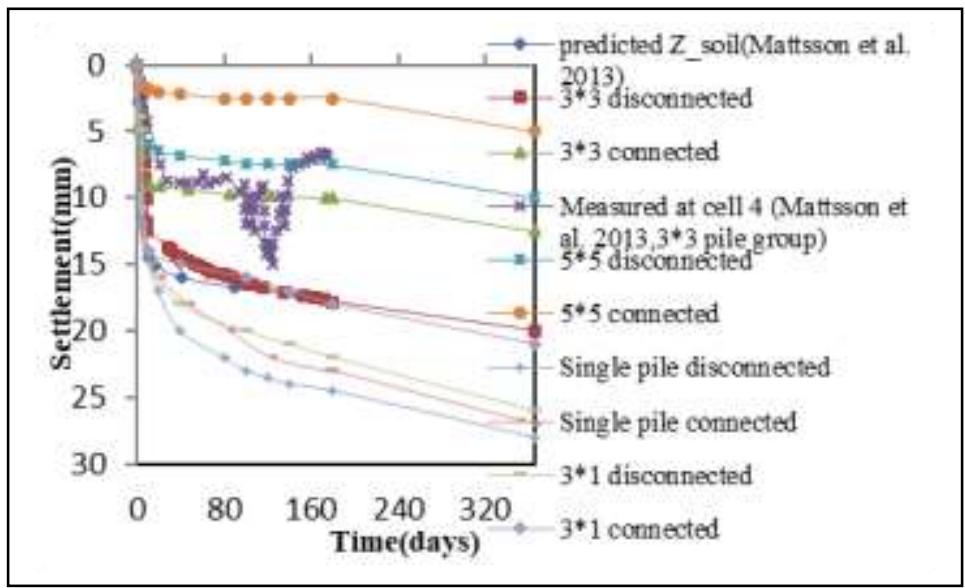

Fig. 6: Settlement of inclusion heads for both disconnected and connected piled raft foundation for a period of 365 days.

\section{Conclusions}

Based on the current study, the following conclusions are drawn.

I. Disconnected and connected piled-raft foundations of single pile, $3 \times 1,3 \times 3$ and $5 \times 5$ pile groups have been analysed using PLAXIS 3D. The reported soil profile and pile dimensions given by Mattsson et al. (2013) have been considered in the analysis. The raft dimension varies according to the configuration of pile groups. The present analysis by PLAXIS 3D has been validated with the reported field test results (Mattsson et al. 2013) and found to be within an error of $22 \%$ for the settlement of concrete slab.

II. The settlements of pile heads of $3 \times 1,3 \times 3$ and $5 \times 5$ connected piled rafts are about $7.17 \%$ to $87.77 \%$ less than the settlement of single connected piled raft for about 1 month to 1 year The settlements of concrete slab and pile heads in case of $5 \times 5$ connected piled-raft foundation are observed to be least as compared to other connected and disconnected piled rafts for a period of one year.

\section{References}

[1] M. M. Eslami, A. Aminikhah, and M. M. Ahmadi, "A comparative study on pile group and piled raft foundations (PRF) behavior under seismic loading," Comp. Meth. Civil Eng., vol. 2, no. 2, pp. 185-199, 2011.

[2] PLAXIS 3D 2013, Netherlands.

[3] K. Horikoshi, T. Matsumoto, Y. Hashizume, T. Watanabe, and H. Fukuyama, "Performance of piled raft foundations subjected to static horizontal loads," Int. J. Phys. Model., vol. 3, no. 2, pp. 37-50, 2003 a.

[4] K. Horikoshi, T. Matsumoto, Y. Hashizume, T. Watanabe, and H. Fukuyama, "Performance of piled raft foundations subjected to dynamic loading," Int. J. Phys. Model., vol. 3, no. 2, pp. 51-62, 2003b.

[5] K. Asutosh, D. Choudhury and R. Katzenbach, "Effect of Earthquake on Combined Pile-Raft Foundation," Int. J. Geomech., vol. 16, no. 5, p. 04016013, 2016.

[6] Kumar, and D. Choudhury, "DSSI analysis of pile foundations for an oil tank in Iraq," Proc., ICE Geotechnical Engineering, vol. 169, no. 2, pp. 129-138, 2016.

[7] T. Matsumoto, H. Nemoto, H. Mikami, K. Yaegashi, T. Arai, and P. Kitiyodom, "Load tests of piled raft models with different pile head connection conditions and their analyses," Soils Found., vol. 50, no. 1, pp. 63-81, 2010.

[8] N. Mattsson, A. Menoret, C. Simon, and M. Ray, "Case study of a full-scale load test of a piled raft with an interposed layer for a nuclear storage facility," Ge'otechnique , vol. 63, no. 11, pp. 965-976, 2013.

[9] A. Mishra, and N.R. Patra, "Time-Dependent Settlement of Pile Foundations Using Five-Parameter Viscoelastic Soil Models," Int. J. Geomech., vol. 18, no. 5, p. 04018020, 2018.

[10] H. G. Poulos, "Piled raft foundations: design and applications," Ge'otechnique, vol. 51, no. 2, pp. 95-113, 2001. 
[11] J. C. Small, and H. H. Zhang, "Behaviour of piled raft foundations under lateral and vertical loading," Int. J. Geomech., vol. 2, no. 1, pp. 29-45, 2002.

[12] Zace, Z_soil PC 2010, User manual, soil, rock and structural mechanics in dry or partially saturated media. Lausanne, Switzerland: ZACE Services Ltd., 2010.

[13] M. Y. Fattah, M. J. Al-Mosawi, and A. A. O. Al-Zayadi, "Time dependent behaviour of piled raft foundation in clayey soil," Geomechanics and Engineering, vol. 5, no. 1, pp. 17-36, 2013.

[14] H. G. Poulos, "An approximate numerical analysis of pile-raft interactions," International Journal for Numerical and Analytical Methods in Geomechanics; vol. 18, pp. 73-94, 1994.

[15] A. Sinha, and A.M. Hanna, "3D Numerical Model for Piled Raft Foundation," Int. J. Geomech., vol. 17, no. 2, p. $04016055,2016$.

[16] J. M. Abbas, Z. H. Chik, M.R. Taha, and Q. S. M. Shafiqu, "Time-dependent lateral response of pile embedded in elasto-plastic soil," J. Cent. South Univ. Technol., vol. 17, pp. 372-380, 2010.

[17] J. C. Small, and H. L. S. Liu, "Time-settlement behaviour of piled raft foundations using infinite elements,"Computers and Geotechnics, vol. 35, pp. 187-195, 2008. 